\title{
THE EFFECT OF PLACEMENT EXPOSURE AND PLACEMENT PROMINENCE ON RECOGNITION, ATTITUDE, AND TRAVEL INTENTION OF TOURISM DESTINATION IN REALITY TELEVISION SHOW
}

\author{
Stacia R. Mege \\ University of Indonesia
}

\begin{abstract}
Previous studies of tourism have proven that inclusion of destination in movies and television serials can induce tourism. This study aims to investigate the effect of destination placement in reality television show. The author will study the interaction of exposure to destination placement and the placement prominence toward recognition, attitude, and intention to visit of participants to the destination. An experimental study using videos of Korean reality show-Running Man will be run on groups of participants. The expected results are as follows. Prominent placement will be more recognized than subtle placement. Participants who will be exposed to destination placement will have higher attitude than those who don't. And attitude is expected to mediate effect of destination placement to intention to visit. The results expected from this research will enrich the literature of product placement from two perspectives, the product (tourism destination) and the media (reality show). The result of this study will be useful for destination marketing organization to explore alternative promotional media.
\end{abstract}

Keywords: Product placement, Reality television, Tourism, Destination Marketing, Attitude, Intention to visit.

\section{Introduction}

Tourism is a crucial asset of a country in which can help increase the country's GDP (Perez-Rodriguez et al., 2015; Besana \& Bagnasco, 2014). The positive impact of tourism can be seen as well in the increasing of local and foreign investment (Sannassee \& Seetanah, 2015). On the other hand, the growth of the tourism industry itself is deeply impacted by global economy condition (Kavaratzis, 2005). Looking at the situation where they are connected to each other, prompts the tourism destination, destination marketing organization, and government to look for more creative way in promoting the destinations.

The diminishing of the effectiveness of traditional travel advertisement prompts the destination marketing organization to shift to audiovisual media to promote tourism destination (Riley \& Van Doren, 1992). Motion picture has been an area of study related to tourism promotion since around two decades ago 
(Riley, Baker, \& van Doren, 1998; Tooke \& Baker, 1996; Riley \& van Doren, 1992). Studies on film tourism have emerged from case studies to more empirical studies (Kim \& Richardson, 2003; Shani et al, 2009; Hudson et al, 2011). Not restricted to motion picture or films, the study of the impact of embedding destination in media has also reached the TV dramas such as Winter Sonata, and Dae Janggeum (Su et al., 2011; Kim et al., 2007).

The studies on the impact of film tourism on destination has proven that depicting the destination on motion pictures has changed people's perception about the location image, alter their attitude and increase travel intention (Kim \& Richardson, 2003; Shani et al., 2009; Su et al., 2011). However, on the other side, depicting a destination on film or drama can cause disappointment and dissatisfaction (Buchmann et al., 2010; Connell \& Meyer, 2009). It happens because motion picture and drama are presented to audiences not as authentic as it is should be.

Authenticity is one of the important indicators in studying film-induced tourism (Buchmann et al., 2010). Reality TV program projects more authentic images to viewers (Tessitore et al., 2014). It makes reality TV program is a perfect environment for product placement, as well as destination placement (Tessitore et al., 2014). Reality TV program has gained popularity and became one of the frequently watched television program (Rose \& Wood, 2005). Tessitore et al., (2014) has investigated the impact of depicting a destination in a reality show, and found that the perception of viewers of the destination, changed after watching the reality show, as well as the attitude and travel intention.

This study will investigate deeper understanding on the impact of depicting destination on reality TV program based on the product placement perspective. Product placement is the act of placing a brand in mass media programing without consumers' awareness (Balasubramanian, 1994). The products inserted in the media, can be differentiate by its prominence, plot connection, and modality or presentation. This study will investigate the impact of destination placement with difference prominence level, which is prominent and subtle.

\section{Literature Review}

\section{Film Tourism}

Hudson and Ritchie (2006) define film tourism as an activity of visiting a specific destination as a result of watching a movie in which the destination is depicted. This is in line with Buchmann et al., (2010) definition which define film tourism as a visitation to the site or location where the film has taken place or places associated with the movie. The studies of film tourism have emerged for more than two decades, started by a group of writers (Riley \& van Doren, 1992; Tooke \& Baker, 1996; Riley, Baker, \& Van Doren, 1998). The focus of research on film tourism can be classified into four categories (Hudson \& Ritchie, 2006; Macionis, 2004): 1) the influence of film on the tourist decision to travel to the destination in the film; 2) literature on the film tourism itself; 3) the impact of film tourism on the increasing numbers of tourist visits, the positive and negative 
impact to the environment and also the residents; and 4) the destination marketing related activities before and after the movie is released.

The impact of film tourism on the numbers of tourist visits becomes one of the most studies found on film tourism and they are nominated by case studies (Tooke \& Baker, 1996; Riley et al., 1998; Beeton, 2005). Meanwhile the studies on influence of film on tourist motivation to travel and destination image are also increasing (Kim \& Richardson, 2003; Kim et al., 2007; Kim et al., 2009; Shani et al., 2009; Hudson et al., 2011).

Compare to the case studies literature, there are less empirical studies on film tourism. Kim \& Richardson (2003) investigated the viewers' perception toward depicted place through a movie and their travel intention to that place on a post-test only control group experiment. The writer found that the cognitive and affective image of Vienna is affected by the movie in both positive and negative ways. However, no significant relationship was found between emphatic involvements, which they suggested as the framework, with the perception of the location (Kim \& Richardson, 2003). Compared to the control group, the visitation interest of participants in the experiment group were significantly higher.

Shani et al., (2009) also studied the impact of movie on the perception of destination image. The depicted destination was South America in the movie The Motorcycle Diaries; meanwhile the participants were students from North American country. By conducting pre-test and post-test experiment, the writer evaluated the effect of movie theme with a controversial plot on the perception and travel intention to South America. It was found that watching the movie did not significantly alter the destination image of South America. The result indicated that the perception of South America images just got strengthened by watching the movie. Even with a controversial plot, Shani et al., (2009) found that there was increasing travel intention to South America.

Utilizing the same movie as Shani et al., (2009) as the stimuli, The Motorcycle Diaries, Hudson et al., (2011) measured the immediate impact of viewers' perception and travel intention to South America. Unlike Shani et al., (2009), this study compared the result between viewers from USA, Canada, and Spain by conducting within group experiment. The result showed that the movie altered the viewers' perception of South America and increased the travel intention respectively.

In generals, these several studies found that movie generated both positive and negative impact of the destination image or the perception about the location. However, regardless of the perception formed in the mind of viewers, the consistent result found on the travel intention.

Macionis (2004) tried to build understanding of film tourism by underlining the Push and Pull Factor Theory of Motivation (Dann, 1977). The pull factors are place, personality, and performance (Macionis, 2004). Place as a pull factor can be examines by location attributes, scenery, landscapes, culture and others. While personality focuses about the cast, characters, and celebrity. The last one, performance is about the storyline, themes, and genre. 


\section{Destination Placement in Reality TV}

Reality show is one type of TV shows that entertain the viewers by showing real people as they live out the real event (Nabi et al., 2003). Reality TV program or reality show serves the same position as movie or film and is a good environment for product placement (Tessitore et al., 2014). The diminishing effectiveness of traditional advertisement (Riley \& Van Doren, 1992) prompts the marketer to find other media in promoting their brands. Reality show is one of the media with emerging popularity (Rose \& Wood, 2005) as it became one of the most frequently watched TV program. Reality shows as well as films have superiority over traditional tourism advertisings. They can reach much wider audiences, not limited to travellers, but more general audiences (Tessitore et al., 2014).

In conducting the study, Tessitore et al., (2014) elaborated the needs of reaching wider audiences without leaving the target audiences of the tourism destination advertisement. Hence, it is necessary to consider which genre of reality show appropriate for the tourism destination itself. There are several types of reality show that can be outlined. The most famous one is competition/elimination reality show. In this type of reality show, the contestants are competing against each other to win the competition. Reality shows that can be included in this subgenre are for example Idols, The Amazing Race, Masterchef, Dancing with a star, Next Top Model, and many others. There are also dating reality show, hidden camera, documentaries, and other genre that will not be elaborated further here. In regard to these various genres, to meet the fit between the destination and the program is necessary (Tessitore et al., 2014). Romantic destination place such as Maldives maybe more appropriate if embedded on dating reality show. More adventurous destination such as Thailand or India will fit more on competition or game reality show such as The Amazing Race.

Another advantage of using reality show rather than film is the authenticity. Buchmann et al., (2010) investigated the film tourism in the context of authenticity. Connell and Meyer's (2009) research on the filming location of Balamory, found that there was a mismatch between the expectations from the tourist and what they experience in real situation when they visit the destination. This could lead to tourists' dissatisfaction and disappointment toward the location or destination (Connell and Meyer, 2009). Here, reality show serves the authenticity by picturing people real emotions, behaviour, personality and others.

Tessitore et al., (2014) research about the impact of inserting destination in reality show was the initial research of destination placement in reality show. The writer conducted within and between subject experiments. The research found that reality show can change the image of the destination in which the show taken place. The writer uses the Dutch version of The Amazing Race, entitled India Celebrity Express which is located in India. The viewers' knowledge about India increases, so does the perception, attitude and travel intention to India.

In order to be able to experience the effect of film tourism, the destination marketing organization or the related party of tourism destination could promote their location to the film-maker or producers (Connell, 2012), so their location 
will be the filming location or depicted in the film. Cost inducement, product differentiation, or accommodation service for the filming crew play the role as the promotional tools by DMO (Connell, 2012). The same promotional tool is applicable to reality show. Moreover, promoting to reality show producers is less expensive than movie (Tessitore et al., 2014). Tourism Australia once invited the popular South Korean TV show entitled Running Man to carry out the filming in Australia. During three episodes in Australia, Running Man casts and crews traveled to several destinations in Australia such as Tanggaloma Island, Curumbin Sanctuary, Brisbane, and Melbourne. Other countries such as RRC, Hongkong, Thailand, and Indonesia have made appearance in several of Running Man episodes. The current paper will investigate the impact of the exposure of destination on reality show, Running Man.

\section{Placement Prominence}

Russell \& Belch (2005) defines product placement as the act of inserting a brand to an entertainment media as a combination of advertising and publicity and designed to influence the audiences without them knowing. The characteristic of product placement can be differentiated into three dimensions, modality, prominence, and plot connection. Modality is the presence of the brand in the form of visual or auditory (Law \& Braun, 2000; Russell, 2002). The level of visual placement can be varying based on the size, duration, centrality, position, frequency, and others, likewise, the level of auditory placement, frequency, emphasizing, and others. This level of visual and auditory is well known as the prominence (Gupta \& Lord, 1998). Meanwhile, plot connection (Russell, 1998; 2002) is the degree of the brand is connected to the story.

Placements with high level of prominence are more frequently mentioned or emphasized (Dens et al., 2012), placed more central to the screen, or displayed longer throughout the scene (Cowley \& Barron, 2008). On the other hand, subtle placements are mentioned or showed less prominently, smaller size, shorter time exposure, placed as background and others (Gupta \& Lord, 1998; Cowley \& Barron, 2008; Dens et al., 2012). By the nature of its appearance, numbers of studies have found that prominent placement is more likely to be recognized than subtle placement (Law \& Braun, 2000; Lehu \& Bressoud, 2008; Dens et al., 2012; Gillespie et al., 2012) and more likely to attract viewers' attention (Gupta \& Lord, 1998).

In destination placement, tourism destination plays the role of the brand. The focus of this paper is to investigate whether the prominently placed destination will generate higher recognition the subtle one.

\section{Hypothesis}

Placement prominence plays an important role in the effectiveness of the product placement. Prominently placed brands have produces greater impact on recognition than the subtle placement (Gupta \& Lord, 1998; Cowley \& Barron, 2008). A vast range of studies on product placement has investigated the explicit memory of viewers when they are exposed to product placement in different characteristic (Law \& Braun, 2000). Two types of explicit memory measurement 
commonly used in the study of product placement are recall and recognition (Yang \& Ewoldsen, 2007). Viewers' explicit memory is activated by the person themselves when they try to gather the information exposed to them beforehand (Yang \& Ewoldsen, 2007). Prominent placement is more recognizable than the subtle one (Law \& Braun, 2000; Lehu \& Bressoud, 2008; Dens et al., 2012; Gillespie et al., 2012). Hence our first hypothesis is:

$\mathrm{H}_{1} \quad$ : Prominently placed destination leads to higher recognition than subtly placed destination

Shani et al., (2009) found that the exposure to destination in the movie, The Motorcycle Diaries, changed the affective image negatively related to the image of South America portrayed in the movie. Kim \& Richardson (2003) on the other hand found only one affective image variable to be significant. Russell (1998) in her study of product placement proposed the Adapted Meaning Transfer Model (AMTM) to understand how product placement works. It is suggested that when viewers watching movie, they will visualize themselves as the character in the movie that they can experience using a brand shown in the movie. It also can be applied to destination portrayed in the movie or reality show. People can imagine visit the destination through vicarious experience (Kim \& Richardson, 2003). Moreover, Tessitore et al., (2014) found that the exposure to destination at reality show shifted viewers' attitude toward India more favorably, supported by the authenticity of the show. Hence, the second hypothesis is as follows.

$\mathrm{H}_{2} \quad$ : Exposure to destination placement leads to more favorable attitude regardless of the prominence level

Regardless of the affective image or attitude toward the destination, the viewers still showing intention to travel to the destinations (Kim \& Richardson, 2003; Shani et al., 2009; Hudson et al., 2011). Tessitore et al., (2014) also found the same result in the study of reality show.

$\mathrm{H}_{3} \quad$ : Exposure to destination placement in reality show will increase people's travel intention to the destination regardless of the prominence level

\section{Methodology}

An experiment will be conducted to investigate the recognition, attitude and travel intention of reality shows' viewers toward the location depicted in the show. The experiment groups will be consists of two groups, which are prominent and subtle placement, and another control group. Participants in the experiment groups will be given video stimuli and will be asked to complete a questionnaire afterwards. Participants in the control group will not be given stimuli and only asked to complete a questionnaire.

The video stimulus is an episode of Running Man's (South Korean TV Show) race taken place in Thailand. The show itself is chosen for several reasons; first, this is a popular game show which will be enjoyed by the participants; 
second, this show has gained worldwide popularity and seen by young people; third, this show has depicted many locations in almost its every episode, including locations in South Korea and abroad. Some countries, such as Australia, Hongkong, Thailand, China, Makau, and Indonesia have been depicted in this show for several episodes. Based on the pre-test conducted to university students, asking them to mention three countries they want to visit on vacation, Thailand has quite low frequency of being mentioned, which is perfect to use as a stimuli to avoid the popular destination.

The experiment will be conducted online with participants from two different universities in North Sulawesi. The participants are randomly assigned to experiment and control groups. The participants will watch the video stimuli at home and complete the questionnaire directly after watching. By conducting the research online where participants watch the video by themselves at home increases the internal validity of the research. The questions to investigate the recognition, attitude, and intention to visit are given to participants in the experiment groups, while participants in the control group will not receive the recognition test. To cover up the original purpose of the research, the participants are asked several questions about the content of the shows, their familiarity with the show, and also their familiarity with several countries including Thailand.

To measure the recognition rate, participants are asked to respond whether the specific location was seen in the video stimuli. The correct respond will be marked 1 , and the wrong respond is 0 . Attitude toward Thailand was assessed by the statements used in Tessitore et al., (2014). Travel intention to Thailand will be measured using the 4-item 7-point scale as outlined by Shani et al., (2009).

\section{References}

Balasubramanian, S. K. (1994). Beyond advertising and publicity: Hybrid messages and public policy issues. Journal of Advertising, 23, 29-46.

Beeton, S. (2005). Film-induced tourism. Clevedon, UK: Channel View Publication in Su, H. J., Huang, Y. A., Brodowsky, G., \& Kim, H. J. (2011). The impact of product placement on TV-induced tourism: Korean TV dramas and Taiwanese viewers. Tourism Management ,32, 805-814.

Besana, A., \& Bagnasco, A, M. (2014). Rethinking tourism in macroeconomics. Procedia Economics and Finance, 14, 58 - 67.

Buchmann, A., \& Moore, K., Fisher, D. (2010). Experiencing film tourism: Authenticity \& Fellowship. Annals of Tourism Research, 37, 229 - 248

Connell, J., \& Meyer, D. (2009). Balamory revisited: An evaluation of the screen tourism destination - tourist nexus. Tourism Management, 30, 194 - 207.

Connell, J. (2012) Film tourism - evolution, progress, and prospects. Tourism Management, 33, 1007 - 1029.

Cowley, E., \& Barron, C. (2008). When product placement goes wrong: The effects of product liking and placement prominence. Journal of Advertising, 37 (1), $89-98$.

Dann, G. M. S. (1977). Anomie, ego-enhancement in tourism. Annals of Tourism Research, 4, 184-194. 
Dens, N., Pelsmacker, P. D., Wouters, M., \& Purnawirawan, N. (2012). Do you like what you recognize? The effect of brand placement prominence and movie plot connection on brand attitude as mediated by recognition. Journal of Advertising, 41, 35-53.

Gillespie, B., Joireman, J., \& Muehling, D. D. (2012). The moderating effect of ego depletion on viewer brand recognition and brand attitudes following exposure to subtle versus blatant product placements in television programs. Journal of Advertising, 41, 55-65.

Gupta, P. B., \& Lord, K. R. (1998). Product placement in movies: The effect of prominence and mode on audience recall. Journal of Current Issues and Research in Advertising, 20, 47-59.

Hudson, S., \& Ritchie, B. (2006). Promoting destinations via film tourism: an empirical identification of supporting marketing initiatives. Journal of Travel Research, 44, 387-396.

Hudson, S., Wang, Y., \& Gil, S. M. (2011). The influence of a film on destination image and the desire to travel: A cross-cultural comparison. International Journal of Tourism Research, 13, 177-190).

Kavaratzis, M. (2005). Place branding: A review of trends and conceptual model. The Marketing Review, 5, 329-342.

Kim, H. J., Chen, M. H., \& Su, H. J. (2009). The Impact of Korean TV dramas and Taiwanese tourism demand for Korea. Tourism Economics, 15 (4), 6773.

Kim, H., \& Richardson, S. (2003). Motion picture impacts on destination images. Annals of Tourism Ressearch, 30, 216-237.

Kim, S. S., Agrusa, J., Lee, H., \& Chon, K. (2007). Effects of Korean television dramas on the flow of Japanese tourists. Tourism Management, 28, 13401353.

Law, S., \& Braun, K. A. (2000). I'll have what she's having: Gaughing the impact of product placements on viewers. Psychology and Marketing, 17 (12), 1059-1075.

Lehu, J. M., \& Bressoud, E. (2008). Effectiveness of brand placement: New insights about viewers. Journal of Business Research, 61, 1083-1090.

Macionis, N. (2004). Understanding the Film-induced tourist. International Tourism and Media Conference Proceedings, 86-97.

Nabi, R. L., Biely, E. N., Morgan, S. J., \& Stitt, C. R. (2003). Reality-based television programming and the psychology of its appeal. Media Psychology, 5, 303-330.

Perez-Rodriguez, J. V., Ledesma-Rodriguez, F., \& Santana-Gallego, M. (2015). Testing dependence between GDP and tourism's growth rates. Tourism Management, 48, 268-282.

Riley, R., \& Van Doren, C. S. (1992). Movies as tourism promotion: A pull factor in push location. Tourism Management, 13, 267-274.

Riley, R., Baker, D., \& Van Doren, C. (1998). Movie-induced tourism. Annals of Tourism Research, 25 (4), 919-935.

Rose, R. L., \& Wood, S. L. (2005). Paradox and the consumption of authenticity through reality television. Journal of Consumer Research, 32, 284-296.

Russell, C. A. (1998). Toward a framework of product placement: Theoritical Propositions. Advances in Consumer Research, 25, 357-362. 
Russell, C. A., \& Belch, M. (2005). A managerial investigation into the product placement industry. Journal of Advertising Research, 45.

Russell, C. (2002). Investigating the effectiveness of Product placements in television shows: the role of modality and plot connection congruence on brand memory and attitude. Journal of Consumer Research, 29, 306-318.

Sannassee, R. V., \& Seetanah, B. (2015). The influence of Trust on Repeat Tourism: The Mauritian Case Study. Journal of Hospitality Marketing \& Management.

Shani, A., Wang, S., Hudson, S., \& Gil, S. M. (2009). Impacts of a historical film on the destination image of South America. Journal of Vacation Marketing, 15(3), 229-242.

Su, H. J., Huang, Y. A., Brodowsky, G., \& Kim, H. J. (2011). The impact of product placement on TV-induced tourism: Korean TV dramas and Taiwanese viewers. Tourism Management ,32, 805-814.

Tessitore, T., Pandelaere, M., \& Kerckhove, A. A. (2014). The amazing race to India: Prominence in reality television affects destination image and travel intentions. Tourism Management, 42, 3-12.

Tooke, N., \& Baker, M. (1996). Seeing is believing: The effect of film on visitor numbers to screened locations. Tourism Management, 17, 87-94.

Yang, M., \& Ewoldsen, D. (2007) The effectiveness of brand placements in the movies: levels of pacements, explicit and implicit memory, and brandchoice behavior. Journal of Communication. 